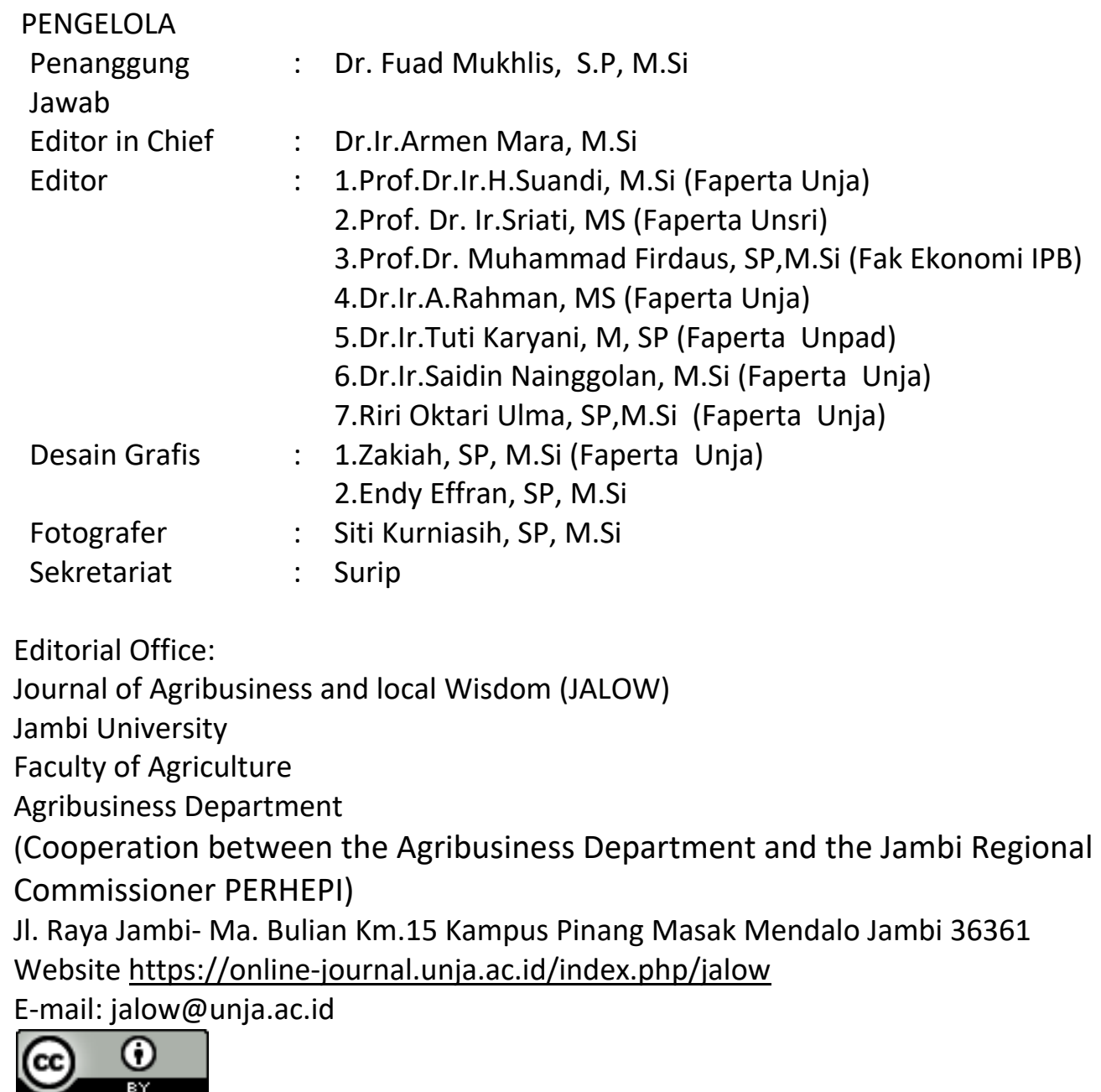

This work is licensed under a Creative Commons Attribution 4.0 International License. 


\section{Assalamualaikum wbwb}

\section{PENGANTAR}

Kondisi agribisnis tahun 2020 ini agak berbeda dengan tahun sebelumnya. Kebijakan penanggulangan Covid19 seperti "dirumah Aja, lockdown lokasi, Isolasi Mandiri, PSBB (Pembatasan Sosial Berskala Besar), dan Herd Immunity" telah merubah pola aktivitas masyarakat, khususnya di Kota-kota. Sebelumnya, berkejar2an dengan waktu untuk meningkatkan pendapatan dengan jalan menambah produktivitas dan menekan biaya telah dikagetkan oleh adanya ancaman pandemi Covid19 yang ada dimana-mana, semangat berkejar-kejaran tersebut kendur seketika.

Kegiatan perdagangan di Kota-kota besar maupun kota kecil telah mengalami kelesuan untuk semua lapisan, mulai dari pedagang kecil mikro, pedagang asongan atau gerobak, pedagang toko, mini market sampai perdagangan berskala besar, super market, dan mallmall. Hal ini menyebabkan terjadinya pengangguran, berkurangnya pendapatan masyarakat dan menurun drastisnya penerimaan pemerintah dari pajak. Selama masa isolasi, para konsumen melakukan belanja dengan sangat hati-hati. Pihak produsen merasakan berkurangnya permintaan. Oleh karena itu, walaupun kebijakan Covid19 tidak menghambat aktivitas produksi pertanian di lahan secara langsung namun karena permintaan berkurang maka berkurang pula pendapatan petani yang mengusahakan kebun atau sawah.

Kebiasaan konsumen yang selama ini lebih banyak makan di luar rumah berubah menjadi lebih banyak makan di rumah sendiri, masak sendiri atau pesan antar. Berbelanja yang semula mencari tempat2 yang banyak di kerumuni orang berubah ke tempat yang tidak ada kerumunannya, artinya rasa enak dan harga murah tidak lagi menjadi patokan utama bagi konsumen. Mereka lebih mengutamakan sehat dan terjamin dalam proses pembuatannya. Kesadaran adanya ancaman bahaya serangan Covid19 terhadap nyawa setiap orang telah menyebabkan berubah nya psikologi dan sosial masyarakat. Sebelumnya berpikir materialis dan untung rugi dari setiap kerja, sekarang mulai nampak adanya kepedulian terhadap perintah agama melaksanakan sholat dan bersedekah. Mulai terlihat adanya aktivitas sosial di tengah-tengah kota, ada kegiatan membagikan nasi bungkus kepada kaum duafah dan lapisan bawah, kegiatan membagikan sembako, membagikan ampelop berisi uang kertas, sampai pada aktivitas memberikan tip berupa uang dalam setiap kali berbelanja di pedagang-pedagang kecil.

Harapan untuk semua aktivitas-aktivitas positif tersebut berlangsung tidak sementara tapi menjadi karakter bagi setiap orang. Kalau aktivitas sosial ini terus dipertahankan oleh pelaku yang telah memulai nya tentu akan diikuti juga oleh yang lainnya. Diharapkan juga setiap pelaku agribisnis berskala kecil, baik yang disektor produksi pertanian maupun sektor industri pengolahan dan perdagangan dapat mengantisipasi perubahan prilaku konsumen tersebut dengan perubahan pola produksi yang sesuai sehingga peluang bisnis yang terlepas dari pola sebelumnya dapat ditangkap.

Demikian semoga JALOW untuk penerbitan ini bermanfaat untuk kita semua aamiin ya robbal aalamiin.

Waalaikumsalam wbwb

Editor in Chief

Dr.Ir.Armen Mara,M.Si 
DAFTAR ISI

\begin{tabular}{|c|c|c|}
\hline 1 & $\begin{array}{l}\text { ANALISIS RESPON PENAWARAN KOMODITI KEDELAI } \\
\text { DI KABUPATEN TANJAB TIMUR } \\
\text { Oleh Edison }\end{array}$ & $1-10$ \\
\hline 2 & 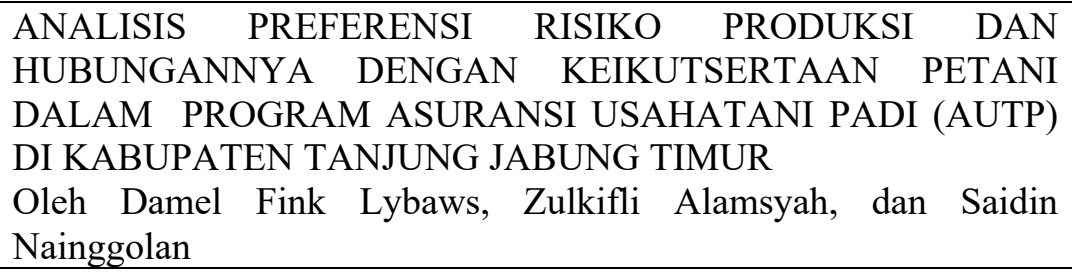 & $11-27$ \\
\hline 3 & $\begin{array}{l}\text { ANALISIS USAHA IKAN HIAS AIR TAWAR DI KOTA JAMBI (ANALYSIS } \\
\text { OF FRESH WATER ORNAMENTAL FISH IN JAMBI CITY) } \\
\text { Dody Hadisaputra, Ernawati, Suandi }\end{array}$ & $28-40$ \\
\hline 4 & $\begin{array}{l}\text { ANALISIS FAKTOR-FAKTOR YANG MEMPENGARUHI PRODUKSI } \\
\text { BOKAR (BAHAN OLAH KARET) DI KABUPATEN BATANGHARI } \\
\text { Oleh Elisabeth Lumban Gaol, Armen Mara, dan Riri Oktari UIma }\end{array}$ & $41-52$ \\
\hline 5 & $\begin{array}{l}\text { ANALISIS PENGAMBILAN KEPUTUSAN UNTUK PEMBELIAN } \\
\text { MAKANAN KEMASAN BERLOGO HALAL MUI (STUDI KASUS IBU } \\
\text { RUMAH TANGGA DI PERUMAHAN AUR DURI DAN PERUMNAS KOTA } \\
\text { BARU, KOTA JAMBI) } \\
\text { Oleh Putri Hana Jusia, Saad Murdy, Lavlinesia }\end{array}$ & $53-66$ \\
\hline 6 & \begin{tabular}{lrrrr} 
STRATEGI & ADAPTASI & PETANI & DALAM & \multicolumn{2}{l}{ MENGHADAPI } \\
RENDAHNYA & HARGA & JUAL & KELAPA & SAWIT DI \\
KECAMATAN & SUNGAI & BAHAR & KABUPATEN & MUARO \\
JAMBI & & & \\
Oleh Fiona Andini & ), Fuad Muchlis $^{2}$ ), Aulia Farida 2) \\
\end{tabular} & $67-73$ \\
\hline 7 & \begin{tabular}{lcllr}
\multicolumn{2}{l}{ KOLABORASI } & DALAM & PENGELOLAAN & \multicolumn{2}{c}{ PERKEBUNAN } \\
KELAPA SAWIT & RAKYAT & (STUDI KASUS: KUD & LUBUK \\
KARYA DAN & KUD & KAMPUNG & SURAU & KAB. \\
DHARMASRAYA & & & & \\
Oleh Yulistriani & & & & \\
\end{tabular} & $74-81$ \\
\hline 8 & $\begin{array}{l}\text { KEPUTUSAN PETANI SAWIT DALAM MENGKONVERSI } \\
\text { LAHAN KELAPA SAWIT MENJADI LAHAN PADI SAWAH DI } \\
\text { KECAMATAN BATANG ASAM KABUPATEN } \\
\text { TANJUNG JABUNG BARAT } \\
\text { Oleh Krielson Ompusunggu1), Arsyad Lubis2, Siti Kurniasih2 }\end{array}$ & $82-88$ \\
\hline 9 & $\begin{array}{l}\text { KAITAN BIAYA DAN TEKNIK PEREMAJAAN } \\
\text { KELAPA SAWIT RAKYAT } \\
\text { Oleh Nur Imdah Minsyah }\end{array}$ & $89-99$ \\
\hline 10 & $\begin{array}{l}\text { STRATEGI RANTAI PASOK KELAPA SAWIT DI PROVINSI } \\
\text { SUMATERA BARAT } \\
\text { Oleh Rahma Dzulqa1*), Rika Ampuh Hadiguna2) }\end{array}$ & 100 \\
\hline
\end{tabular}




\title{
ANALISIS PENGAMBILAN KEPUTUSAN UNTUK PEMBELIAN MAKANAN KEMASAN BERLOGO HALAL MUI (STUDI KASUS IBU RUMAH TANGGA DI PERUMAHAN AUR DURI DAN PERUMNAS KOTA BARU, KOTA JAMBI)
}

\author{
Putri Hana Jusia ${ }^{1)}$, Saad Murdy ${ }^{2)}$, Lavlinesia ${ }^{3)}$ \\ 1) Mahasiswa Program Studi Megister Agribisnis Fakultas Pertanian Universitas Jambi \\ ${ }^{2)}$ Staf Pengajar Program Studi Megister Agribisnis Fakultas Pertanian Universitas \\ Jambi \\ Email : putrihanajusia@gmail.com
}

\begin{abstract}
Food is a basic need that must be available all the time for human survival. Food as a source of energy must be of high quality. In 2016, the Indonesia Ministry of Health issued a program on the consumption of nutrition and safety food. Indonesia is the country with the most Muslim population in the world with $87.17 \%$ of the total Indonesian population of 255,461,700 people (BPS, 2015). It is well known that to get proper food by an individual is consider as ones' right that must be satisfy. Therefore, food as a strategic commodity perceive to satisfy the right of an individual to obtain a proper consumption of food. Halal food does not only cover religious aspects. Halal certified products have gone through the production process which takes quality, processing, and cleanliness of a product into account. The demand for halal food products is increasing and has been widely proven on the market implementation. Not only in Muslim-majority countries but in developed countries which do have high living standards including standards for quality assurance of food products. The respondents of the study are household wives reside in Aur Duri Residential and Kota Baru Residential, Jambi. The study collected 96 respondents who filled up the surveys. Moreover, the study signified that there are 43 (44\%) respondents who prefer the MUI Halal logo affect their purchase intention. It is influenced by characteristics in terms of religion, age and education. Knowledge, compliance based on beliefs, and awareness of quality assurance and food security affects the perceptions of household wives to the decision to purchase food with halal logo MUI packaging. The marketing strategy that most influences the purchase intention on an individual are price and products that become daily necessities.
\end{abstract}

Key words: Purchase decision, MUI Halal logo.

\section{PENDAHULUAN}

Pangan adalah kebutuhan dasar untuk kelangsungan hidup manusia. Pangan sebagai sumber energi harus berkualitas sangat penting untuk menunjang tubuh yang sehat, aktif, cerdas, dan produktif. Indonesia dalam total pengeluaran dari sektor makanan berada diurutkan pertama, yaitu sebesar 190,4 miliar \$ atau sekitar $18 \%$ dari total pengeluaran global untuk sector makanan sementara dari sector obat-obatan berada di posisi ke tiga terbesar. Konsumsi masyarakat Indonesia yang belum mencerminkan pola makanan sehat yang menjadi faktor penyebab tingginya konsumsi obat di Indonesia. Pada tahun 2016 Kementerian pertanian dan kesehatan. mengeluarkan program pola konsumsi pangan Beraga, Bergizi dan Aman (B2SA). Pangan Aman adalah pangan yang tidak menyebabkan gangguan kesehatan pada manusia.

Manusia selalu berusaha mendapatkan makanan yang baik dan halal (berdasarkan keyakinan). Halal bukan hanya mencakup aspek agama tetapi halal juga berkaitan dengan proses produksi yang memperhatikan kualitas, pengolahannya dan kebersihan suatu produk yang baik untuk dikonsumsi. Produk yang bersertifikat halal sudah melalui proses tersebut. Permintaan akan produk pangan halal semakin meningkat dan telah 
diimplementasikan kian meluas, tidak hanya di negara mayoritas muslim tetapi di negara maju yang memiliki standar hidup yang tinggi termasuk untuk standar akan jaminan mutu produk pangan.

Seiring dengan perkembangan zaman manusia semakin sibuk dengan pekerjaan dalam persaingan global dan meningkatnya pendidikan serta semakin mudahnya dalam mendapatkan informasi. Manusia dituntut semakin cepat dalam beraktivitas, cenderung memilih hal-hal yang praktis dan semakin selektif untuk memenuhi kebutuhan. Produk pangan dalam kemasan dapat menjadi salah satu alternatif untuk memenuhi kebutuhan pangan masyarakat karena pangan kemasan memiliki daya tahan yang lebih tahan lama dan praktis, serta mudah dalam pengolahannya. Pada kemasan pangan biasanya dicantumkan label sebagai identitas produk. Label sebagaimana dimaksud memuat sekurang-kurangnya keterangan mengenai: (a) nama produk; (b) daftar bahan yang digunakan; (c) berat bersih atau isi bersih; (d) nama dan alamat pihak yang memproduksi atau memasukkan pangan ke dalam wilayah Indonesia; (e) keterangan tentang halal; dan (f) tanggal, bulan, dan tahun kedaluarsa (UU RI No.8, 2012).

Di Indonesia lembaga yang berwenang melegalkan status halal adalah oleh Lembaga Pengkajian Pangan Obat-obatan, Kosmetik dan Majelis Ulama Indonesia (LPPOM MUI). Sertifikasi halal MUI adalah fatwa tertulis Majelis Ulama Indonesia yang menyatakan kehalalan suatu produk sesuai dengan syariat Islam. Sertifikat halal MUI ini merupakan syarat untuk mendapatkan izin pencantuman logo halal MUI pada kemasan produk.

Logo halal MUI dapat menjadi sarana komunikasi yang efektif kepada konsumen. Pencantuman logo halal MUI pada kemasan produk dapat menjadi indikator untuk memudahkan konsumen memilih pangan halal. Logo halal MUI juga berperan sebagai identitas sebuah produk sehingga dengan melihat logo halal pada kemasan konsumen muslim merasa yakin akan jaminan mutu dan kehalalan.

OIC (Organization of Islamic Cooperation) dari hasil "Pew Research Center's Forum on Religion \& Public Life" memproyeksikan total penduduk muslim dunia akan meningkat dari 1,6 miliar jiwa di tahun 2010 menjadi 2,2 miliar jiwa di tahun 2030 dengan pertumbuhan $1,5 \%$ pertahanannya atau mendekati $30 \%$ dari total penduduk dunia. Indonesia dengan jumlah penduduk 255.461 .700 jiwa dengan $87,17 \%$ merupakan negara yang memiliki jumlah muslim terbanyak di dunia yang tentunya memiliki ukuran pasar muslim urutan pertama di dunia yaitu 190,4 \$ tahun 2013 (Purnomo, 2015).

Tabel 1. Ukuran Pasar konsumsi muslim dunia tahun 2015

\begin{tabular}{|l|c|}
\hline NAMA NEGARA & Ukuran Pasar Konsumsi Muslim (dalam miliar USD) \\
\hline Indonesia & 190,4 \\
Turki & 168,5 \\
Pakistan & 108,4 \\
Iran & 96,0 \\
Mesir & 94,8 \\
\hline
\end{tabular}

Sumber :State of The Global Islamic Economy Report 2014-2015

Mempelajari perilaku konsumen berarti mempelajari bagaimana konsumen membuat keputusan untuk menggunakan sumber daya yang dimilikinya (waktu, uang dan usaha) untuk memperoleh barang atau jasa yang diinginkan. Perilaku konsumen dalam pengambilan keputusan pembelian merupakan aktivitas keseharian dalam memenuhi 
kebutuhan pangan yang dikonsumsi untuk kelangsungan hidup. Berdasarkan Undangundang RI (UU JPH) Jaminan Produk Halal pada tanggal 25 September 2014 terhitung tahun 2019 , seluruh produk yang beredar wajib memiliki sertifikat halal. Hal ini akan mendorong para pelaku usaha untuk bergerak menuju industri halal. Implementasi dari UU JPH secara potensial akan meningkatkan kepercayaan dan daya saing produk Indonesia terhadap jaminan kehalalan baik untuk memenuhi kebutuhan dalam negeri dan meraih peluang pasar halal di manca negara. Bagi produsen logo halal MUI berperan sebagai media komunikasi, memberikan nilai tambah dan daya saing pada produk sehingga meningkatkan jumlah pelanggan setia serta pada akhirnya memberikan keuntungan secara berkelanjutan bagi pelaku usaha.

Keputusan adalah perumusan beraneka pilihan yang tepat antara beberapa alternatif yang tersedia. Pengambilan keputusan sebagai proses penting untuk dipahami dalam pemasar. Pengambilan keputusan dapat dipandang sebagai suatu sistem yang terdiri dari input, proses dan output. Prosesnya seperti disajikan pada Gambar 3 (Suryani, 2008).

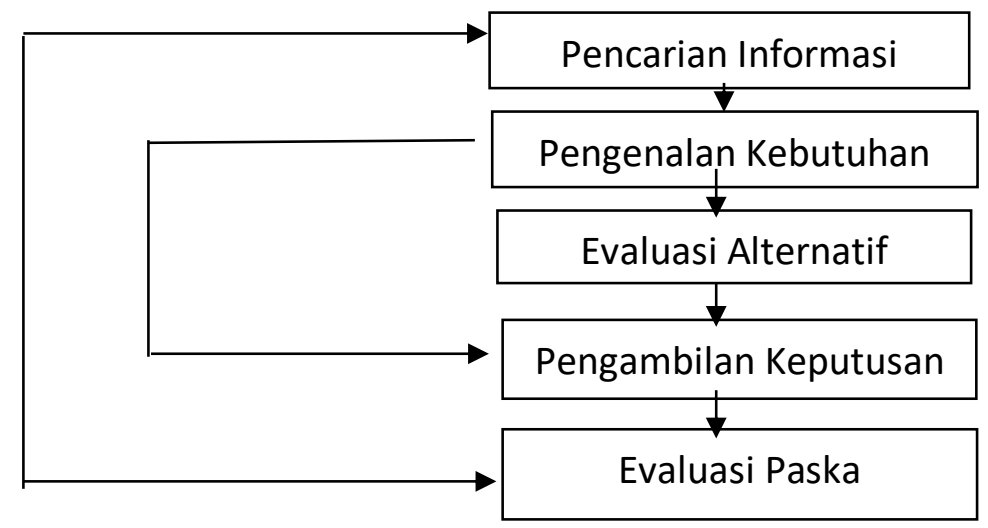

Gambar 2. Proses Pengambilan Keputusan

Berdasarkan pada gambar diatas, ada lima hal yang berkaitan dengan proses keputusan konsumen. Proses ini diawali dengan pengenalan kebutuhan oleh konsumen, diikuti dengan pencarian informasi, evaluasi alternatif, pengambilan keputusan dan evaluasi paska membeli. Setelah membeli produk, konsumen akan mengalami level kepuasan atau ketidakpuasan tertentu. Tugas pemasar tidak berakhir begitu saja ketika produk dibeli. Peran pemasar harus memantau kepuasan paska pembelian, saat pembelian, dan pemakaian produk setelah pembelian sebagai layanan konsumen.

Keluarga (family) dapat diartikan sebagai sekelompok individu yang terdiri dari dua atau lebih orang yang berhubungan darah, pernikahan atau adopsi yang tinggal bersama. Keluarga terdiri dari: a) Keluarga inti (nuclear family) adalah kelompok langsung yang terdiri dari ayah, ibu, dan anak yang tinggal bersama. b) Keluarga besar (extended family) mencakup keluarga inti, beserta kerabat lain, seperti kakek-nenek, paman-bibi, sepupu dan kerabat karena perkawinan. Anggota keluarga merupakan kelompok acuan primer yang paling berpengaruh. Keluarga merupakan organisasi pembelian konsumen yang paling penting dalam masyarakat. Keputusan konsumsi keluarga dapat melibatkan lima peranan yang dapat didefinisikan sebagai berikut :

1) Penjaga pintu (gatekeeper), inisiator pemikiran keluarga mengenai pembelian produk dan pengumpulan informasi untuk membantu pengambilan keputusan. 
2) Pemberi pengaruh (influencer), individu yang opini dicari sehubungan dengan kriteria yang harus digunakan oleh keluarga dalam pembelian dan produk atau merek mana yang paling mungkin cocok dengan kriteria evaluasi.

3) Pengambil keputusan (decider), orang dengan wewenang atau kekuasaan keuangan untuk memilih bagaimana uang keluarga akan dibelanjakan dan produk atau merek apa yang akan dipilih.

4) Pembeli (buyer), orang yang bertindak sebagai agen pembelian yang mengunjungi toko, menghubungi penyuplai, menulis cek, membawa produk ke rumah, dan seterusnya.

5) Pemakai (user), orang yang menggunakan produk.

Keluarga memiliki struktur sendiri, seperti juga yang terjadi pada masyarakat, dimana setiap anggota memainkan perannya masing-masing. Bagi pemasar adalah penting untuk membedakan peran setiap anggota keluarga dalam tujuan untuk mengoptimalkan strategi pemasaran. Asumsi yang dibuat mengenai peran-peran pembelian harus dicek melalui riset konsumen sehingga pemasar dapat membuat bauran pemasaran yang tepat. Konsep siklus hidup keluarga atau rumah tangga telah terbukti sangat bermanfaat.

\section{METODOLOGI PENELITIAN}

Penelitian dilaksanakan dalam bentuk survei pada ibu rumah tangga dengan pengambilan simpel secara acak di Perumahan Aur Duri dan Perumahan Kota Baru. Kedua perumahan tersebut dijadikan lokasi penelitian dengan pertimbangan merupakan perumahan yang sudah lama dan aspek sosial serta sarana pendukungnya lainnya pejabat perangkat, pasar, masjid, sekolah dan lapangan .

Ruang lingkup penelitian dibatasi pada pengambilan keputusan untuk pembelian makanan kemasan berlogo halal Data yang diteliti sebagai berikut :

1. Data kependudukan di Perumahan Aur Duri dan di Perumahan Kota Baru.

2. Data karakteristik Ibu rumah tangga di Perumahan Aur Duri dan di Perumahan Kota Baru.

3. Data keputusan pembelian makanan kemasan terhadap keberadaan berlogo halal MUI di Perumahan Aur Duri dan di Perumahan Kota Baru.

4. Preferensi konsumen adalah hanya memilih atau tidak hanya memilih produk yang dikonsumsi berlogo Halal MUI.

5. Keputusan Halal adalah perilaku dan keyakinan responden untuk mematuhi perintah ajaran agama Islam tentang konsumsi pangan halal (skor).

6. Halal Awareness adalah kesadaran atau kepedulian responden terhadap produk pangan kemasan berlogo halal MUI (skor).

7. Kepercayaan terhadap SOP sertifikasi halal MUI melegalkan kehalalan produk (skor).

8. Loyalitas adalah komitmen pelanggan bertahan untuk berlangganan kembali secara konsisten untuk membelanjakan sumber daya yang dimilikinya terhadap keberadaan logo halal MUI (skor).

Sumber data menggunakan data primer dan data sekunder. Data primer diperoleh melalui metode wawancara survei dengan pengisian kuesioner yang telah dirancang yang diambil secara sengaja. Skala likert untuk mengukur sikap/persepsi yang beragam dari segi kepatutan halal, pengetahuan, halal awareness, kepercayaan dan loyalitas sebagai 
faktor independen terhadap preferensi/ keputusan konsumen (Peduli atau tidak Peduli produk pangan dalam kemasan berlogo halal MUI) sebagai faktor dependen. Data sekunder sebagai data pendukung diperoleh dari BPS Kota Jambi dan lain-lain.

Metode pengambilan sampel yang digunakan adalah pendekatan Slovin dengan presisi yang digunakan $10 \%$ dari populasi dan dapat formulasi sebagai berikut:

$$
n=\frac{\mathrm{N}}{\mathrm{N}\left(d^{2}\right)+1}
$$

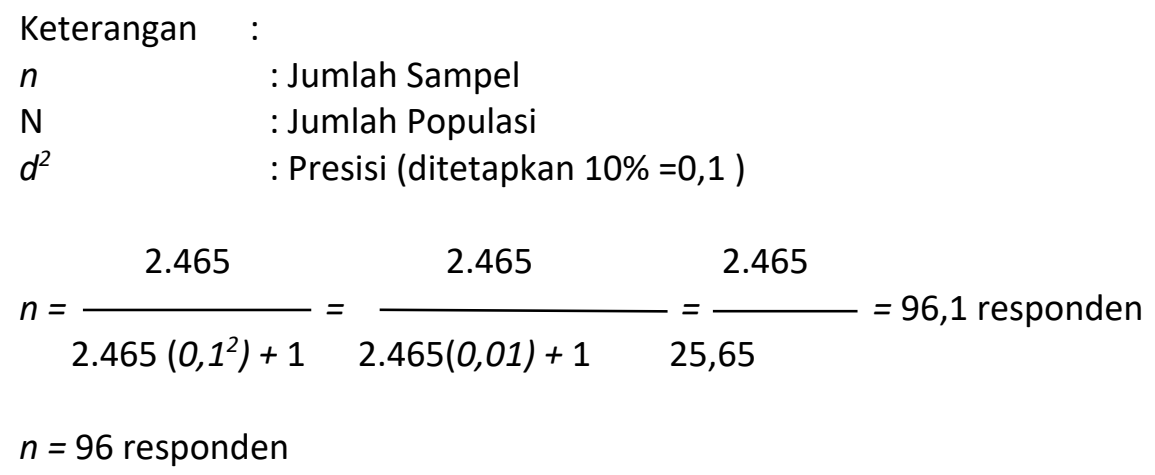

Dalam penelitian ini digunakan ketetapan $10 \%$ untuk analisis data deskriptif kepada 96 responden yang di Perumahan Aur Duri dan Perumahan Kota Baru. Kemudian distribusi di setiap Perumahan secara proporsional random samping dengan rumus :

\begin{tabular}{ll} 
& \multicolumn{1}{c}{$\quad n i=$} \\
Keterangan & $: \quad$ Ni.n \\
$\mathrm{i}$ & : Jumlah Sampel \\
$\mathrm{Ni}$ & : Jumlah Populasi \\
$\mathrm{N}$ & : Jumlah Populasi Keseluruhan \\
$\mathrm{n}$ & : Jumlah Sampel Seluruhnya
\end{tabular}

Tabel 2 Rincian Sebaran Sampel di Perumahan Aur Duri dan Perumahan Kota Baru Kota Jambi.

\begin{tabular}{lcccc}
\hline No & Perumahan & $\begin{array}{c}\text { Jumlah Penduduk } \\
\text { (Jiwa) }\end{array}$ & Jumlah KK & $\begin{array}{c}\text { Jumlah } \\
\text { Sampel }\end{array}$ \\
\hline 1. & Aur Duri & 7.395 & 1.291 & 51 \\
2. & Kota Baru & 3.957 & 1.174 & 45 \\
\hline Jumlah & 11.352 & 2.465 & 96 \\
\hline
\end{tabular}

Sumber : Bps Kota Jambi Tahun 2017

Data hasil survei wawancara diperoleh dan dikelompokkan menggunakan data kuantitatif dan data kualitatif. Data kuantitatif digunakan untuk mengidentifikasi karakteristik responden dengan cara mengelompokkan berdasarkan usia, tingkat pendidikan, pendapatan rumah tangga, pengeluaran konsumsi per bulan, dan jumlah tanggungan keluarga ke dalam table statistik. Data Kualitatif digunakan untuk mengetahui presepsi responden dalam mengambil keputusan pembelian makanan kemasan dengan bantuan 
skala likert dengan bantuan grafik. Analisa korelasi berganda dan analisa korelasi dengan konsep pengukuran senagai berikut :

1. Keputusan pembelian adalah Suatu tahap dimana konsumen telah memiliki pilihan dan siap untuk melakukan pembelian atau pertukaran antara uang dan janji untuk membayar dengan hak kepemilikan atau penggunaan suatu barang atau jasa. Dalam penelitian ini dimana keputusan yang dimaksud adalah keputusan dalam membeli makanan kemasan berlogo halal MUI.

2. Karakteristik Ibu rumah tangga meliputi : agama, umur, pendidikan, status pekerjaan, jumlah anggota keluarga dalam satu rumah, pengeluaran konsumsi per bulan.

3. Persepsi Ibu rumah tangga meliputi : Pengetahuan, Kepatuhan, Kesadaran tentang halal dan kepercayaan terhadap logo halal MUI serta loyalitas konsumen untuk kesediaan membayar dengan harga yang lebih tinggi.

\section{HASIL DAN PEMBAHASAN}

Karakteristik Ibu Rumah Tangga di Perumahan Aur Duri dan Perumahan Kota Baru Kota Jambi

Karateristik ibu rumah tangga di perumahan Aur Duri dan Perumahan Kota Baru Kota Jambi dapat di lihat pada Tabel 3. Pada Tabel 3 terlihat karateristik dari segi agama, umur, pendidikan, status pekerjaan, jumlah anggota keluarga yang tinggal dalam satu rumah dan pengeluaran konsumsi per bulan. 
Tabel 3. Karakteristik Ibu Rumah Tangga di Perumahan Aur Duri dan Perumahan Kota

\begin{tabular}{|c|c|c|c|c|c|c|c|}
\hline \multirow{3}{*}{ Variabel } & \multirow{3}{*}{ Sub-variabel } & \multicolumn{6}{|c|}{$\begin{array}{l}\text { Preferensi responden Peduli berlogo halal MUI } \\
\text { pada keputusan pembelian }\end{array}$} \\
\hline & & \multicolumn{2}{|c|}{ Peduli } & \multicolumn{2}{|c|}{ Tidak Peduli } & \multicolumn{2}{|c|}{ Total } \\
\hline & & Jumlah & $\%$ & Jumlah & $\%$ & Jumlah & $\%$ \\
\hline \multirow[t]{7}{*}{ Agama } & Islam & 52 & 59 & 36 & 41 & 88 & 92 \\
\hline & Kristen & - & - & 7 & 100 & 7 & 7 \\
\hline & Buddha & - & - & 1 & 100 & 1 & 1 \\
\hline & Hindu & - & - & - & - & - & - \\
\hline & Katolik & - & - & - & - & - & - \\
\hline & Kong Hu cu & - & - & - & - & - & - \\
\hline & Jumlah & 52 & 54 & 44 & 46 & 96 & 100 \\
\hline Umur & $<19$ tahun & 3 & 43 & 4 & 57 & 7 & 7 \\
\hline \multirow[t]{5}{*}{ Tahun } & 20-29 tahun & 5 & 20 & 20 & 80 & 25 & 26 \\
\hline & 30-39 tahun & 8 & 27 & 22 & 73 & 30 & 31 \\
\hline & 40-49 tahun & 16 & 80 & 4 & 20 & 20 & 21 \\
\hline & $>50$ tahun & 12 & 86 & 2 & 14 & 14 & 15 \\
\hline & Jumlah & 44 & 46 & 52 & 54 & 96 & 100 \\
\hline \multirow{5}{*}{$\begin{array}{l}\text { Pendidikan } \\
\text { Terakhir }\end{array}$} & SD/MI/Sederajat & 3 & 20 & 12 & 80 & 15 & 16 \\
\hline & SMP/MTs/Sederajat & 7 & 41 & 10 & 59 & 17 & 18 \\
\hline & SMA/SMK/MA/Sederajat & 16 & 42 & 22 & 58 & 38 & 40 \\
\hline & Diploma/Sarjana & 16 & 62 & 10 & 38 & 26 & 27 \\
\hline & Jumlah & 42 & 44 & 54 & 56 & 96 & 100 \\
\hline Status & URT/Pekerja Keluarga & 25 & 49 & 26 & 51 & 51 & 53 \\
\hline \multirow[t]{4}{*}{ Pekerjaan } & Pekerja Bebas & 3 & 20 & 12 & 80 & 15 & 16 \\
\hline & Kariawan Tetap & 8 & 44 & 10 & 56 & 18 & 19 \\
\hline & Wirausaha & 4 & 33 & 8 & 67 & 12 & 13 \\
\hline & Jumlah & 40 & 42 & 56 & 58 & 96 & 100 \\
\hline Jumlah & $<3$ orang & 15 & 34 & 29 & 66 & 44 & 46 \\
\hline Anggota & $4-5$ orang & 21 & 88 & 3 & 13 & 24 & 25 \\
\hline \multirow[t]{3}{*}{ Keluarga } & 6-7 orang & 4 & 17 & 19 & 83 & 23 & 24 \\
\hline & $>8$ orang & 2 & 40 & 3 & 60 & 5 & 5 \\
\hline & Jumlah & 42 & 44 & 54 & 56 & 96 & 100 \\
\hline Tingkat & $<\operatorname{Rp} 1.000 .000$ & 7 & 39 & 11 & 61 & 18 & 19 \\
\hline Pengeluar & $R p 1.000 .001-R p$ & & & & & & \\
\hline an & 2.000 .000 & 17 & 39 & 27 & 61 & 44 & 46 \\
\hline \multirow{4}{*}{$\begin{array}{l}\text { Konsumsi } \\
\text { per bulan }\end{array}$} & Rp 2.000.001 - Rp & & & & & & \\
\hline & 3.000 .000 & 5 & 31 & 11 & 69 & 16 & 17 \\
\hline & $>\operatorname{Rp} 3.000 .001$ & 13 & 72 & 5 & 28 & 18 & 19 \\
\hline & Jumlah & 42 & 44 & 54 & 56 & 96 & 100 \\
\hline
\end{tabular}

Sumber data survei di Perumahan Aur Duri Perumahan Kota Baru.

Survei berdasarkan agama $92 \%$ responden beragama Islam dan yang non muslim berkisar $8 \%$ yaitu terdiri dari $7 \%$ beragama Kristen dan $1 \%$ beragama Budha. Berdasarkan Tabel 4 agama yang diyakini Ibu-ibu mempunyai hubungan sangat sebesar 31,9\% yang menjadikan logo halal MUI sebagai indikator penentuan kehalalan.

Tabel 4 Hasil Analisis Korelasi Agama dengan Preferensi Peduli Pada Pangan Kemasan Berlogo Halal MUI di Perumahan Aur Duri dan Perumahan Kota Baru 


\begin{tabular}{llccc}
\hline & & \multicolumn{3}{c}{ Korelasi } \\
Peduli & Muslim & Non muslim \\
\hline Memilih & Pearson & 1 &, $319^{* *}$ &,$- 319^{* *}$ \\
& Correlation & &, 001 &, 001 \\
& Sig. (2-tailed) & & 96 & 96 \\
\multirow{4}{*}{ Muslim } & $\mathrm{N}$ & 96 & 1 & $-1,000^{* *}$ \\
& Pearson &, $319^{* *}$ & & 0,000 \\
& Correlation &, 001 & 96 & 96 \\
& Sig. (2-tailed) & 96 & $-1,000^{* *}$ & 1 \\
Non & $\mathrm{N}$ &,$- 319^{* *}$ & 0,000 & \\
& Pearson &, 001 & 96 & 96 \\
& Correlation & 96 & &
\end{tabular}

**. Korelasi sangat signifikan pada taraf 0.01 .

Tabel 5 Hasil Analisis Korelasi antara Umur Responden dengan Preferensi Memilih Pada Pangan Kemasan di Perumahan Aur Duri dan Perumahan Kota Baru

\begin{tabular}{|c|c|c|c|c|c|c|c|}
\hline & & Memilih & $\begin{array}{l}\text { Korelasi } \\
\text { Tahun } \\
<19\end{array}$ & $\begin{array}{l}\text { Tahun } \\
20-29\end{array}$ & $\begin{array}{l}\text { Tahun } \\
30-39\end{array}$ & $\begin{array}{l}\text { Tahun } \\
40-49\end{array}$ & $\begin{array}{l}\text { Tahun } \\
>50\end{array}$ \\
\hline \multirow[t]{3}{*}{ Memilih } & $\begin{array}{l}\text { Pearson } \\
\text { Correlation }\end{array}$ & 1 &,- 169 & , $323^{* *}$ & ,388** &, $218^{*}$ &,$- 254^{*}$ \\
\hline & Sig. (2-tailed) & & 099 & ,001 & ,000 & ,032 & ,012 \\
\hline & $\mathrm{N}$ & 96 & 96 & 96 & 96 & 96 & 96 \\
\hline \multirow[t]{3}{*}{$\begin{array}{l}\text { Tahun } \\
<19\end{array}$} & $\begin{array}{l}\text { Pearson } \\
\text { Correlation }\end{array}$ &,- 169 & 1 &,- 173 &,- 132 &,- 124 &,- 100 \\
\hline & Sig. (2-tailed) & 099 & & ,090 & 198 & 226 & ,331 \\
\hline & $\mathrm{N}$ & 96 & 96 & 96 & 96 & 96 & 96 \\
\hline \multirow[t]{3}{*}{$\begin{array}{l}\text { Tahun } \\
20-29\end{array}$} & $\begin{array}{l}\text { Pearson } \\
\text { Correlation }\end{array}$ &,$- 323^{* *}$ &,- 173 & 1 &,$- 477^{* *}$ &,$- 276^{* *}$ &,$- 222^{*}$ \\
\hline & Sig. (2-tailed) & ,001 & 090 & & ,000 & ,006 & ,029 \\
\hline & $\mathrm{N}$ & 96 & 96 & 96 & 96 & 96 & 96 \\
\hline \multirow[t]{3}{*}{$\begin{array}{l}\text { Tahun } \\
30-39\end{array}$} & $\begin{array}{l}\text { Pearson } \\
\text { Correlation }\end{array}$ & ,388** &,- 132 & $477^{* *}$ & 1 &,$- 341^{* *}$ &,$- 275^{* *}$ \\
\hline & Sig. (2-tailed) & ,000 & 198 & ,000 & & 001 & ,006 \\
\hline & $\mathrm{N}$ & 96 & 96 & 96 & 96 & 96 & 96 \\
\hline \multirow[t]{3}{*}{$\begin{array}{l}\text { Tahun } \\
40-49\end{array}$} & $\begin{array}{l}\text { Pearson } \\
\text { Correlation }\end{array}$ &, $218^{*}$ &,- 124 & $276^{-}$ &,$- 341^{* *}$ & 1 &,- 159 \\
\hline & Sig. (2-tailed) & ,032 & 226 & ,006 & ,001 & & 120 \\
\hline & $\mathrm{N}$ & 96 & 96 & 96 & 96 & 96 & 96 \\
\hline \multirow[t]{3}{*}{$\begin{array}{l}\text { Tahun } \\
>50\end{array}$} & $\begin{array}{l}\text { Pearson } \\
\text { Correlation }\end{array}$ &,$- 254^{*}$ &,- 100 &,$- 222^{*}$ &,$- 275^{* *}$ &,- 159 & 1 \\
\hline & Sig. (2-tailed) & ,012 & ,331 & ,029 & ,006 & ,120 & \\
\hline & $\mathrm{N}$ & 96 & 96 & 96 & 96 & 96 & 96 \\
\hline
\end{tabular}

**. Korelasi sangat signifikan pada taraf 0.01 .

* Korelasi signifikan pada taraf 0.05 .

Hasil survei umur ibu-ibu sebagai responden yang termuda 18 tahun dan yang tertua 58 tahun. Umur ibu dikelompokkan menjadi lima kelompok yaitu yang termuda dibawah 19 tahun sebesar 7\%, 20-29 tahun sebanyak $26 \%$, 30-39 tahun sebanyak $31 \%$, 40-49 tahun sebanyak $21 \%$ dan diatas tahun sebanyak 15 
\%. Pada Tabel 7 Hasil Analisis korelasi umur hubungan sangat nyata pada berumur 30-39 tahun (38,8 \%) selang kepercayaan $99 \%$ dan 40-49 tahun $(21,8$ $\%)$ selang kepercayaan $95 \%$ dalam pengambilan keputusan pembelian. Pada umur yang berusia diatas 30 tahun mempunyai pengalaman, informasi dan kematangan emosional untuk memilih yang terbaik untuk dirinya dan keluarganya. Ibu-ibu sebagai responden yang berumur dibawah 29 tahun dan diatas 50 tahun tidak berpengaruh nyata antara logo Halal MUI sebagai indikator dengan pengambilan keputusan pembelian pangan. Hal ini dikarenakan kurangnya informasi dan kesadaran pada ibu-ibu berumur dibawah 29 tahun. Pada ibu-ibu yang berumur diatas 50 tahun kecilnya logo halal MUI pada kemasan pangan sehingga kurang menjadi perhatikan.

Pendidikan yang ditamatkan ibu rumah tangga di Perumahan Aur Duri Perumahan Kota Baru dikelompokkan menjadi 4 kelompok yaitu: SD / MI / Sederajat sebanyak $16 \%$, tingkat SMP / MTs / Sederajat sebanyak $18 \%$. Pendidikan ibu terbanyak pada tingkat SMA / SMK / MA / Sederajat sebanyak $40 \%$. Jenjang pendidikan yang di tamatkan tertinggi Diploma / Sarjana / Master / Doktor sebanyak 27 \%. Status pekerjaan ibu rumah tangga, sebagian besar mengurus rumah tangga / pekerja keluarga sebanyak $53 \%$. Responden yang berkerja sebagai karyawan tetap sebanyak $19 \%$, pekerja bebas $16 \%$ dan persentase yang paling kecil ibu rumah tangga berkerja sebagai wirausaha sebanyak $13 \%$.

Tabel 6 Hasil Analisis Korelasi Pendidikan dengan Preferensi Memilih Pangan Kemasan Berlogo Halal MUI di Perumahan Aur Duri dan Perumahan Kota Bar

\begin{tabular}{|c|c|c|c|c|c|c|}
\hline \multicolumn{7}{|c|}{ Korelasi } \\
\hline & & Memilih & SD & SMP & SMA & Sarjana \\
\hline \multirow[t]{3}{*}{ Memilih } & $\begin{array}{l}\text { Pearson } \\
\text { Correlation }\end{array}$ & 1 &,$- 341^{* *}$ &,$- 373^{* *}$ &, $258^{*}$ &, $393^{* *}$ \\
\hline & Sig. (2-tailed) & & ,001 & ,000 & ,011 & ,000 \\
\hline & $\mathrm{N}$ & 96 & 96 & 96 & 96 & 96 \\
\hline \multirow[t]{3}{*}{ SD } & $\begin{array}{l}\text { Pearson } \\
\text { Correlation }\end{array}$ &,$- 341^{* *}$ & 1 &,$- 212^{*}$ &,$- 327^{* *}$ &,$- 283^{* *}$ \\
\hline & Sig. (2-tailed) & ,001 & & ,037 & ,001 & ,005 \\
\hline & $\mathrm{N}$ & 96 & 96 & 96 & 96 & 96 \\
\hline \multirow[t]{3}{*}{ SMP } & $\begin{array}{l}\text { Pearson } \\
\text { Correlation }\end{array}$ &,$- 373^{* *}$ &,$- 212^{*}$ & 1 &,$- 351^{* *}$ &,$- 304^{* *}$ \\
\hline & Sig. (2-tailed) & ,000 & ,037 & & ,000 & ,002 \\
\hline & $\mathrm{N}$ & 96 & 96 & 96 & 96 & 96 \\
\hline \multirow[t]{3}{*}{ SMA } & $\begin{array}{l}\text { Pearson } \\
\text { Correlation }\end{array}$ &, $258^{*}$ &,$- 327^{* *}$ &,$- 351^{* *}$ & 1 &,$- 420^{* *}$ \\
\hline & Sig. (2-tailed) & ,011 & ,001 & ,000 & & ,000 \\
\hline & $\mathrm{N}$ & 96 & 96 & 96 & 96 & 96 \\
\hline \multirow[t]{3}{*}{ Sarjana } & $\begin{array}{l}\text { Pearson } \\
\text { Correlation }\end{array}$ &, $393^{* *}$ &,$- 283^{* *}$ &,$- 304^{* *}$ &,$- 420^{* *}$ & 1 \\
\hline & Sig. (2-tailed) & ,000 &, 005 &, 002 & ,000 & \\
\hline & $\mathrm{N}$ & 96 & 96 & 96 & 96 & 96 \\
\hline
\end{tabular}

**. Korelasi sangat signifikan pada taraf 0.01 .

*. Korelasi signifikan pada taraf 0.05 .

Persentase Jumlah anggota keluarga yang Persentase jumlah keluarga dibawah 3 orang yang tinggal dalam satu rumah sebanyak $46 \%$, anggota keluarga 4-5 orang sebanyak $25 \%$. Jumlah anggota keluarga dengan jumlah 6-7 orang sebanyak $24 \%$ dan jumlah keluarga paling banyak yaitu diatas 8 orang yang tinggal dalam satu rumah dengan persentase $5 \%$ dari total keseluruhan. Berdasarkan hasil analisis korelasi penelitian pada 
Tabel 6 terdapat hubungan yang sangat nyata pada ibu-ibu yang pendidikan tertinggi (Diploma/Sarjana/) sebesar 39,3\% dengan selang kepercayaan $99 \%$ terhadap preferensi memilih pangan kemasan berlogo Halal MUI. Ibu-ibu di perumahan Aur Duri dan Perumahan Kota Baru yang berpendidikan SMA / SMK / MA / Sederajat berpengaruh nyata sebesar $25,8 \%$ dengan selang kepercayaan $95 \%$. Ibu-ibu dengan pendidikan SMP dan SD tidak berpengaruh terhadap preferensi pemilihan makanan kemasan. Pendidikan ibu-ibu akan membentuk sikap baik dari penerimaan informasi yang diperoleh termasuk informasi dari logo halal MUI untuk pengambilan keputusan pembelian termasuk ibu yang berada di Perumahan Aur Duri dan Perumahan Kota Baru Kota Jambi.

Tabel 7 Hasil Analisis Korelasi Jumlah Anggota Keluarga dengan Preferensi Memilih Makanan Kemasan Berlogo Halal MUI di Perumahan Aur Duri dan Perumahan Kota Baru.

\begin{tabular}{|c|c|c|c|c|c|c|}
\hline \multicolumn{7}{|c|}{ Korelasi } \\
\hline & & Memilih & Orang <3 & $\begin{array}{c}\text { Orang } \\
4-5\end{array}$ & $\begin{array}{c}\text { Orang } \\
6-7\end{array}$ & $\begin{array}{c}\text { Orang } \\
<8\end{array}$ \\
\hline \multirow[t]{3}{*}{ Memilih } & $\begin{array}{l}\text { Pearson } \\
\text { Correlation }\end{array}$ & 1 &,$- 206^{*}$ &, $210^{*}$ & ,039 & ,024 \\
\hline & Sig. (2-tailed) & &, 043 & 039 & ,703 & 818 \\
\hline & $\mathrm{N}$ & 96 & 96 & 96 & 96 & 96 \\
\hline \multirow[t]{3}{*}{$\begin{array}{l}\text { Orang }< \\
3\end{array}$} & $\begin{array}{l}\text { Pearson } \\
\text { Correlation }\end{array}$ &,$- 206^{*}$ & 1 &,$- 533^{* *}$ &,$- 519^{* *}$ & 193 \\
\hline & Sig. (2-tailed) & ,043 & & ,000 & ,000 & ,058 \\
\hline & $\mathrm{N}$ & 96 & 96 & 96 & 96 & 96 \\
\hline \multirow[t]{3}{*}{$\begin{array}{l}\text { Orang } \\
4-5\end{array}$} & $\begin{array}{l}\text { Pearson } \\
\text { Correlation }\end{array}$ & ,210* &,$- 533^{* *}$ & 1 &,$- 320^{* *}$ & -119 \\
\hline & Sig. (2-tailed) & ,039 & ,000 & & ,001 & 246 \\
\hline & $N$ & 96 & 96 & 96 & 96 & 96 \\
\hline \multirow[t]{3}{*}{$\begin{array}{l}\text { Orang } \\
6-7\end{array}$} & $\begin{array}{l}\text { Pearson } \\
\text { Correlation }\end{array}$ & 039 &,$- 519^{* *}$ &,$- 320^{* *}$ & 1 & -,116 \\
\hline & Sig. (2-tailed) & 703 & ,000 & ,001 & & ,259 \\
\hline & $\mathrm{N}$ & 96 & 96 & 96 & 96 & 96 \\
\hline \multirow[t]{3}{*}{$\begin{array}{l}\text { Orang }< \\
8\end{array}$} & $\begin{array}{l}\text { Pearson } \\
\text { Correlation }\end{array}$ & ,024 &,- 193 &,- 119 &,- 116 & 1 \\
\hline & Sig. (2-tailed) & 818 & ,058 & ,246 & 259 & \\
\hline & $\mathrm{N}$ & 96 & 96 & 96 & 96 & 96 \\
\hline
\end{tabular}

*. Korelasi signifikan pada taraf 0.05 .

**. Korelasi sangat signifikan pada taraf 0.01 .

Berdasarkan hasil analisis korelasi pada Tabel 7 dapat dilihat bahwa jumlah anggota keluarga 4-5 orang berpengaruh nyata sebesar $21 \%$ selang kepercayaan $95 \%$ terhadap preferensi memilih makanan kemasan berlogo halal MUI. Jumlah anggota keluarga 4-5 orang yang terdiri suami, istri dan terdapat 2 atau 3 orang anak dalam satu keluarga termasuk keluarga yang mendekati program keluarga berencana (KB) dan tentunya banyak pertimbangan kebaikan dari KB sebagai program pemerintah. Kebaikan tersebut dari ibu-ibu dalam perhatian pada jaminan mutu dan halal bahan pangan yang di suplai untuk keluarganya dalam batas kontrol yang ideal. Jumlah anggota keluarga yang lebih dari 6 orang tidak terdapat hubungan terhadap pengambilan keputusan pada pangan kemasan berlogo halal MUI. Bertambahnya anggota keluarga dengan pendapatan tetap sama dari pemasukan keluarga lebih banyak dan kurang memperhatikan logo halal MUI sebagai indikator jaminan halal pada makanan kemasan.

Tingkat pengeluaran konsumsi dari keluarga dikelompokkan menjadi 4 yaitu: tingkat pengeluaran konsumsi terkecil yaitu dibawah 1.000 .000 rupiah per bulan dengan 
persentase $19 \%$, kisaran pengeluaran sebagian besar ibu rumah tangga di Perumahan Aur Duri dan Perumahan Kota Baru dengan jumlah 1.000.001-2.000.000 rupiah per bulan sebanyak $46 \%$. Pengeluaran 2.000.001-3.000.000 rupiah per bulan sebanyak $16 \%$ dan tingkat pengeluaran konsumsi tertinggi diatas 3.000.001 rupiah per bulan dengan persentase $19 \%$.

Pengambilan keputusan pembelian dalam memilih makanan kemasan berlogo halal MUI pada ibu rumah tangga sebesar $44 \%$ responden yang hanya memilih dan selebihnya $56 \%$ tidak hanya memilih dari 96 responden. Hal ini menujukkan ibu rumah tangga di Perumahan Aur Duri dan Perumahan Kota Baru di Kota Jambi kurang peduli pada logo halal MUI sebagai indikator jaminan mutu dan halal pada bahan pangan.

Tabel 8 Hasil Analisis Korelasi Pengeluaran Konsumsi per bulan dengan Preferensi Memilih Makanan Kemasan Berlogo Halal MU

\begin{tabular}{|c|c|c|c|c|c|c|}
\hline \multicolumn{7}{|c|}{ Korelasi } \\
\hline & & & & & $2-3$ & $>3$ \\
\hline & & Memilih & $<1$ Juta & 1-2 Juta & Juta & Juta \\
\hline \multirow[t]{3}{*}{ Memilih } & Pearson Correlation & 1 &,- 159 &,$- 296^{* *}$ &, $218^{*}$ &, $321^{* *}$ \\
\hline & Sig. (2-tailed) & & 120 & ,004 & ,032 & ,001 \\
\hline & $\mathrm{N}$ & 96 & 96 & 96 & 96 & 96 \\
\hline \multirow[t]{3}{*}{$<1$ Juta } & Pearson Correlation &,- 159 & 1 &,$- 444^{* *}$ &,$- 212^{*}$ &,$- 228^{*}$ \\
\hline & Sig. (2-tailed) & 120 & & ,000 & 037 & ,025 \\
\hline & $\mathrm{N}$ & 96 & 96 & 96 & 96 & 96 \\
\hline \multirow[t]{3}{*}{ 1-2 Juta } & Pearson Correlation &,$- 296^{* *}$ &,$- 444^{* *}$ & 1 &,$- 413^{* *}$ &, $444^{* *}$ \\
\hline & Sig. (2-tailed) & ,004 & ,000 & & ,000 & ,000 \\
\hline & $\mathrm{N}$ & 96 & 96 & 96 & 96 & 96 \\
\hline \multirow[t]{3}{*}{ 2-3 Juta } & Pearson Correlation &, $218^{*}$ &,$- 212^{*}$ &,$- 413^{* *}$ & 1 &,$- 212^{*}$ \\
\hline & Sig. (2-tailed) & ,032 & ,037 & ,000 & & ,037 \\
\hline & $\mathrm{N}$ & 96 & 96 & 96 & 96 & 96 \\
\hline \multirow[t]{3}{*}{$>3$ Juta } & Pearson Correlation &, $321^{* *}$ &,$- 228^{*}$ &,$- 444^{* *}$ &,$- 212^{*}$ & 1 \\
\hline & Sig. (2-tailed) & ,001 & ,025 & ,000 & ,037 & \\
\hline & $\mathrm{N}$ & 96 & 96 & 96 & 96 & 96 \\
\hline
\end{tabular}

**. Korelasi sangat signifikan pada taraf 0.01 .

*. Korelasi signifikan pada taraf 0.05 .

Hasil analis korelasi pengeluaran konsumsi per bulan dengan preferensi memilih makanan kemasan berlogo halal MUI yang dapat dilihat pada Tabel 8. Pengeluaran konsumsi lebih 3.000 .000 per bulan berpengaruh sangat nyata sebesar $32,1 \%$ selang kepercayaan $99 \%$ dan 21,8 \% selang kepercayaan 95\% terhadap preferensi memilih makanan kemasan berlogo halal MUI. Sementara pengeluaran kurang dari 2 juta tidak berpengaruh nyata terhadap preferensi memilih makanan kemasan berlogo halal MUI.

\section{Persepsi Ibu-ibu di Perumahan Aur Duri dan Perumahan Kota Baru terhadap Pangan Kemasan Berlogo Halal MUI}

Persepsi sangat mempengaruhi pengambilan keputusan pembelian pada produk. Hasil persepsi ibu-ibu di Perumahan Aur Duri dan Perumahan Kota Baru terhadap pangan kemasan berlogo halal MUI beragam dilihat dari pengetahuan konsumen terhadap loga halal, kepatuhan akan perintan agama, kesadaran mengambil keputusan membeli, 
kepercayaan legalitas logo halal dan loyalitas untuk membeli makanan dilihat pada Tabel 9.

Tabel 9 Persepsi Ibu-ibu terhadap Pangan Kemasan Berlogo Halal MUI di Perumahan Aur Duri dan Perumahan Kota Baru Kota Jambi

\begin{tabular}{lcccccccccc}
\hline $\begin{array}{c}\text { Skala } \\
\text { Likert }\end{array}$ & \multicolumn{2}{c}{$\begin{array}{c}\text { Pengetahuan } \\
\text { Peduli }\end{array}$} & \multicolumn{2}{c}{$\begin{array}{c}\text { Kepatuhan } \\
\text { Peduli }\end{array}$} & \multicolumn{2}{c}{$\begin{array}{c}\text { Kesadaran } \\
\text { Peduli }\end{array}$} & \multicolumn{2}{c}{$\begin{array}{c}\text { Kepercayaan } \\
\text { Peduli }\end{array}$} & \multicolumn{2}{c}{$\begin{array}{c}\text { Loyalitas } \\
\text { Peduli }\end{array}$} \\
\hline $\begin{array}{l}\text { Sangat } \\
\text { Tidak } \\
\text { Setuju }\end{array}$ & 6 & 0 & 6 & 0 & 6 & 1 & 0 & 0 & 6 & 1 \\
$\begin{array}{l}\text { Tidak } \\
\text { Setuju } \\
\text { Ragu- }\end{array}$ & 3 & 1 & 0 & 0 & 21 & 4 & 5 & 2 & 6 & 1 \\
$\begin{array}{l}\text { ragu } \\
\text { Setuju }\end{array}$ & 18 & 7 & 30 & 9 & 13 & 5 & 29 & 19 & 17 & 16 \\
$\begin{array}{l}\text { Sangat } \\
\text { Setuju }\end{array}$ & 8 & 26 & 9 & 12 & 12 & 28 & 15 & 19 & 16 & 20 \\
\hline Jumlah & 54 & 43 & 9 & 22 & 2 & 5 & 5 & 3 & 9 & 5 \\
\hline Total & 96 & & 94 & 43 & 54 & 43 & 50 & 39 & 50 & 39 \\
\hline
\end{tabular}

Berdasarkan data penelitian pada Tabel 9 terlihat dari segi pengetahuan makanan halal hanya 26 ibu-ibu sebagai responden yang setuju dan 9 ibu-ibu sebagai responden sangat setuju atau 35,3\% menyatakan ibu-ibu mengetahui tentang halal mempengaruhi dan peduli terhadap pengambilan keputusan pembelian pada makanan kemasan berlogo halal MUI. Dari segi kepatuhan 12 ibu-ibu responden setuju dan 22 ibu-ibu responden sangat setuju hanya 34,7\% menyatakan ibu-ibu di perumahan Aur Duri dan perumahan Kota Baru patuh untuk pembelian makanan kemasan berlogo halal MUI. Dari tingkat kesadaran 28 ibu-ibu responden menyatakan setuju dan 5 responden menyatakan sangat setuju dengan persentase 33,1\% untuk peduli pangan halal MUI yang mempengaruhi pengambilan keputusan pembelian. Kepercayaan tentang logo halal MUI, 16 ibu-ibu responden setuju dan 9 ibu-ibu responden sangat setuju sebanding $25,3 \%$ menyatakan mempercayai logo halal MUI berperan dalam pengambilan keputusan pembelian makanan kemasan.

Dari tingkat loyalitas 20 ibu-ibu responden setuju dan 5 ibu-ibu responden menyatakan sangat setuju. Hanya 25,7 \% ibu-ibu di Perumahan Aur Duri dan Perumahan Kota Baru yang bersedia membayar dengan harga yang lebih tinggi untuk makanan kemasan berlogo halal MUI. Persepsi ibu-ibu di Perumahan Aur Duri dan Perumahan Kota Baru Kota Jambi masih dibawah 35 \% menjadikan berlogo halal MUI mempengaruhi keputusan pembelian pangan kemasan berlogo halal MUI.

Hasil analisis korelasi persepsi ibu-ibu di perumahan Aur Duri dan perumahan Kota Baru untuk membeli makanan kemasan berlogo halal MUI dapat dilihat pada Tabel 10 terlihat hubungan sangat nyata dengan selang kepercayaan $99 \%$ antara variabel kepatuhan (44\%), pengetahuan (35,1\%), dan kesadaran (49\%) terhadap preferensi hanya membeli makanan kemasan berlogo halal MUI. Loyalitas konsumen mempunyai hubungan nyata sebesar $21,5 \%$ dengan selang kepercayaan $95 \%$ terhadap hanya membeli makanan kemasan berlogo halal MUI. Secara keseluruhan Ibu-Ibu di perumahan Aur Duri dan perumahan Kota Baru memilih pangan kemasan berlogo halal MUI. Pemilihan pangan kemasan tentunya berkaitan dengan keyakinan mayoritas penduduk Indonesia $87,17 \%$ adalah muslim. 
Tabel 10 Hasil Analis Korelasi Persepsi Ibu-ibu di Perumahan Aur Duri dan Perumahan Kota Baru untuk Membeli Makanan Kemasan Berlogo Halal MUI

\begin{tabular}{|c|c|c|c|c|c|c|c|}
\hline \multicolumn{8}{|c|}{ Korelasi } \\
\hline & & $\begin{array}{l}\text { Memili } \\
\mathrm{h}\end{array}$ & $\begin{array}{c}\text { Kepatuh } \\
\text { an }\end{array}$ & $\begin{array}{l}\text { Pengeta } \\
\text { huan }\end{array}$ & $\begin{array}{c}\text { Kesadara } \\
n\end{array}$ & $\begin{array}{c}\text { Kepercaya } \\
\text { an }\end{array}$ & Loyalitas \\
\hline \multirow[t]{3}{*}{ Memilih } & $\begin{array}{l}\text { Pearson } \\
\text { Correlation }\end{array}$ & 1 & ,440** & , $351^{* *}$ & ,490** & 156 &, $215^{*}$ \\
\hline & Sig. (2-tailed) & & ,000 & ,000 & ,000 & 128 & ,035 \\
\hline & $\mathrm{N}$ & 96 & 96 & 96 & 96 & 96 & 96 \\
\hline \multirow[t]{3}{*}{ Kepatuhan } & $\begin{array}{l}\text { Pearson } \\
\text { Correlation }\end{array}$ &, $440^{* *}$ & 1 &, $759^{* *}$ &, $607^{* *}$ &, $683^{* *}$ & ,796** \\
\hline & Sig. (2-tailed) & ,000 & & ,000 & ,000 & ,000 & ,000 \\
\hline & $\mathrm{N}$ & 96 & 96 & 96 & 96 & 96 & 96 \\
\hline \multirow[t]{3}{*}{ Pengetahuan } & $\begin{array}{l}\text { Pearson } \\
\text { Correlation }\end{array}$ &, $351^{* *}$ & ,759** & 1 & ,713** &, $645^{* *}$ & ,711** \\
\hline & Sig. (2-tailed) & ,000 & ,000 & & ,000 & ,000 & ,000 \\
\hline & $\mathrm{N}$ & 96 & 96 & 96 & 96 & 96 & 96 \\
\hline \multirow[t]{3}{*}{ Kesadaran } & $\begin{array}{l}\text { Pearson } \\
\text { Correlation }\end{array}$ &, $490^{* *}$ &, $607^{* *}$ &, $713^{* *}$ & 1 &, $566^{* *}$ & ,613** \\
\hline & Sig. (2-tailed) & ,000 & ,000 & ,000 & & ,000 & ,000 \\
\hline & $\mathrm{N}$ & 96 & 96 & 96 & 96 & 96 & 96 \\
\hline \multirow[t]{3}{*}{ Kepercayaan } & $\begin{array}{l}\text { Pearson } \\
\text { Correlation }\end{array}$ & 156 & ,683** & ,645** &, $566^{* *}$ & 1 &, $783^{* *}$ \\
\hline & Sig. (2-tailed) & 128 & ,000 & ,000 & ,000 & & ,000 \\
\hline & $\mathrm{N}$ & 96 & 96 & 96 & 96 & 96 & 96 \\
\hline \multirow[t]{3}{*}{ Loyalitas } & $\begin{array}{l}\text { Pearson } \\
\text { Correlation }\end{array}$ &, $215^{*}$ &, $796^{* *}$ &, $711^{* *}$ &, $613^{* *}$ &, $783^{* *}$ & 1 \\
\hline & Sig. (2-tailed) & ,035 & ,000 & ,000 & ,000 & ,000 & \\
\hline & $\mathrm{N}$ & 96 & 96 & 96 & 96 & 96 & 96 \\
\hline
\end{tabular}

**. Korelasi sangat signifikan pada taraf 0.01 .

*. Korelasi signifikan pada taraf 0.05

\section{KESIMPULAN}

Ibu rumah tangga memiliki peren besar dalam mengatur sumber keuang keluarga akan dibelanjakan dan produk atau merek apa yang akan dipilih untuk memenuhi kebutuhan keluarga. Pengambilan keputusan untuk pembelian makanan kemasan 
berlogo halal MUI di pengaruhi dari karateristik dan prersepsi dari responden. Perumahan Aur Duri dan perumahan kota baru yang berada di kota Jambi. Karateristik yang sangat nyata dengan selang kepercayaan $99 \%$ dari tingkat pendidikan tingkat sarjana 39,3\%, umur ibu dengan kisaran 30-39 tahun 38,8\%, agama islam dan pengeluaran komsumsi < 3.000.000 per bulan hanya $32 \%$ serta jumlah anggota keluarga yang tinggal dalam satu rumah berkisar 4-5 orang hanya $21 \%$ dengan selang kepercayaan $95 \%$ sementara status pekerjaan tidak terdapat hubungan nyata terhadap pengambilan keputusan pembelian kemasan berlogo halal MUI. Presepsi dari ibu-ibu rumah tangga mempunyai hubungan sangat nyata terhadap pengambilan keputusan pembelian makan kemasan berlogo halal MUI dengan selang kepercayaan $99 \%$ dari kesadaran untuk selektip sebelum membeli sebesar $49 \%$, kepatuhan terhadap perintah agama $44 \%$, pengetahuan tentang jaminan halal $35,1 \%$ dan loyalitas untuk hanya membeli hanya $21,5 \%$ dengan selang kepercayaan $95 \%$. Pembelian yang hanya membeli makanan kemasan berlogo halal MUI dari ibu-ibu rumah tangga masih rendah dibawah $50 \%$.

\section{DAFTAR PUSTAKA}

Badan Pusat Statistik. 2015, Jumlah Penduduk Kota Jambi. Badan Pusat Statistik, Jambi. Pemerintah NKRI, 2012. Pasal 1 ayat 1 Undang-undang Republik Indonesia Nomor 18, tentang Pangan.

2011. Peraturan Kepala Badan POM Indonesia Nomor 33, 2014, Tentang Jaminan Produk Halal. Peraturan Kepala Badan POM, 2011, Tata Laksana. 2014., Panduan Umum Sistem Jaminan Halal. LPPOM MUI Semarang. 2014. Pusat Pembinaan dan Pengembangan Bahasa, Kamus Besar Bahasa Indonesia Balai Pustaka, Jakarta.

Pramono W, 2015. Faktor-faktor yang Mempengaruhi Awareness Masyarakat Muslin Kota Bogor Terhadap Produk Olahan Pangan Halal,(Skripsi) Institusi Pertanian Bogor, Bogor.

Suryani, Tatik, 2008 Perilaku Konsumen; Implikasi Pada Strategi Pemasaran, Edisi Pertama, Yogyakarta: Graha Ilmu. 